\title{
Knowledge of Pharmacogenomics in Indian Traditional Medicine -Ayurveda
}

\author{
SN Venugopalan Nair* \\ Trans Disciplinary University, Institute of Trans Disciplinary Health Sciences and Technology, FRLHT, 74/2, Jarakabande Kaval, Post Attur, via Yelahanka, Bangalore 64, \\ Karnataka, India
}

*Corresponding author: SN Venugopalan Nair, Trans Disciplinary University, Institute of Trans Disciplinary Health Sciences and Technology, FRLHT, 74/2, Jarakabande Kaval, Post Attur,via Yelahanka, Bangalore 64, Karnataka, India, Tel: 9108028565847; E-mail: Venu.gopal@frlht.org

Received date: August 11, 2015; Accepted date: August 26, 2015; Published date: August 31, 2015

Copyright: () 2015 Nair SNV. This is an open-access article distributed under the terms of the Creative Commons Attribution License, which permits unrestricted use, distribution, and reproduction in any medium, provided the original author and source are credited.

\begin{abstract}
Charaka (The author of Charaka Samhita, believed to compiled in between 1500BCE-200 AD) explains in Sanskrit"yōgamāsām tu yō vidyāt dēśa kālōpa pāditam, purușam purușam vīkșya sañjēyō sa bhișaguttama:" [1] that "He is the best of physicians who knows how to administer the medicine in accordance with their region (habitation and procurement of medicinal plants) and time and prakrti (Psycho somatic constitution) of each person individually. This is probably the first classical reference in the history of Indian medicine on pharmacogenomics. This review article has in-depth information on concept of Prakrti, - which is the Psycho Somatic constitution or GenotypicPhenotypic expression) of a person. The benefits of knowing your Prakrti, its role in health care and wellness, factors influencing the formation of Prakrti and its relationship with epigenetic factors as understood in Traditional Indian medicine (Ayurveda) are explained. This paper refers to very important correlative studies on Genomics and concept of Prakrti.
\end{abstract}

Keywords: Ayurveda; Prakriti; Pharmacogenomics

\section{Introduction}

In Ayurveda, the biological constitution or the genetic makeup of an individual, which remains constant throughout one's life is called Prakrti. The Prakrti of an individual manifests as the physical attributes and physiological and psychological responses. The knowledge of prakriti is intended (Psycho Somatic constitution) for better health management [1-5].

"Pra" refers to before, beginning, commencement or source of origin, in different contexts. Similarly "kriti" means creation or to do. Therefore, Prakrti on the whole means 'the first formed nature' or 'the original form of the being' [6].

Every individual is a unique entity with a constitution of his/her own. This is called Prakrti. This Prakrti or the biological judiciary controls the physical and mental faculties of an individual.

\section{Prakrti, - Is the Psychosomatic Constitution or Genotypic-Phenotypic Expression}

In nature, we see a great deal of diversity in the features, behaviour, abilities, attitudes, tastes, etc. among humans. Even identical twins are not similar in all respects! What is it that makes an individual unique in his or her own way and hence distinctly different from the others? It is the constitution. The way we are, the way we behave, the way our body reacts to certain things- all these are to a great extent influenced by our 'constitution'- call it biological constitution, genetic constitution or 'Prakrti. It is understood as the extended expression of the genotype of a person [7]

The Prakrti manifests in physical, physiological and psychological feature. Therefore, each Prakrti has certain characteristic features or 'expressions'. Ayurveda lists around 150such expressionsto identify the prakrti of an individual based on general and specific features and its allied symptoms. It is a combination of Psycho Somatic constitution and understood as Genotypic- Phenotypic expression. This is because some attributes are unchangeable from birth to death which denotes it genotypic link and some features are prone to change over a period of time or under influence of environmental stress. It also predicts the possibilities of impending metabolic disorders in a person and helps one to take precautionary measures and design individualized combination of drugs or customized formulations.

\section{The benefits of knowing your Prakrti (Psycho Somatic constitution)}

- It helps you understand your health status and select an appropriate life style (daily and seasonal regimen) to suit your nature [6].

- It helps you understand your attitudes/ tastes, and live appropriately by adjusting with the environment.

- It helps you to take control over your food habits. Selecting food items according to your Prakrti will keep you healthy.

- It helps you be aware about your susceptibility to diseases and to become cautious about food and deeds.

- By taking precautions suggested for a Prakrti, one can prevent diseases.

- It helps identify the nature of your family members or colleagues, thus helping you to interact appropriately with the family and society in harmony.

- As a diagnostic tool, knowledge of Prakrti of the patient helps a physician to understand the course of the disease. This is because; bringing back the individual to his state of equilibrium of doshas ("prakrti-sthapanam") is the aim of the treatment.

- It also helps him to decide appropriate medicines, its dosage, food and regimen for the patient. 
- The prognosis of a disease can be understood easily by a physician if the Prakrti is known very well. For eg. Individuals with VathaPrakrti treatment show good response.

- Restorative treatment or pancha-karma (five purificatory measures) treatment has to be properly adopted according to the constitution in an appropriate season.

- It is possible to customize poly herbal formulations for ones Prakrti (Psycho Somatic constitution) because it is more efficacious and produce no ill effects.

\section{How is the knowledge of Prakrti (Psycho Somatic constitution) helpful in health care and wellness}

Since Prakrti encompasses the entire physical, physiological and psychological features of an individual, the day-to-day life is influenced by one's Prakrti. Knowledge of the same will help to choose the life style suited to one's Prakrti in terms of food habits, physical exercise, rest etc. Choosing the right life style will in turn counter react the ill effects of one's Prakrti to a great extent. The knowledge of one's Prakrti will help the physician in prognosis of diseases and selection of treatment procedures for best results.

In a sociological context, dealing with a particular temperament of an individual appropriately is also possible. For instance the knowledge of a child's Prakrti helps in better parenting.

The criteria of health and wellness (swasthya) vary from person to person and the measure to attain stability also varies. (Sanskrit reference: "swasthasya prakrti bheddena nana prakara, atha thesham hithamapi nana prakaara") and explains the polymorphism.

This also means that Prakrtior constitution of a person determines his health or wellness (swasthya). The Prakrti of a person is fixed during the time of conception (Sanskrit reference: "sukra sonitha samyoge yobhaveth dosha uthkata prakrti jaayathe thena" [1]) and it remains unchanged all through the life. This understanding relates to the Genotype of an Individual.

An individual with optimum health has a balanced Psycho Somatic constitution or "samaprakrti", even though this is a rare phenomenon.

Congenital diseases are the result of deranged functions of the above factors in the uterus. In this context Ayurveda further explains the role of genetic factors which are responsible for the makeup of an individual.

If any part of the beeja-bhaaga (chromosome) or beeja-bhaagaavayava (gene) is not stable during the time of conception or during the period of pregnancy, the corresponding abnormalities of structural and functional disorders can be seen in the offspring [1].

The word Prakrti is translated as Psycho Somatic constitution, temperament, or nature. Prakrti of an individual is the substratum which holds the key to health. As the prakrti is determined during the time of conception and pregnancy various factors related to this can be studied under two main categories. This is explained as Genetic type before and after the birth (1.Garbha sareera-prakrti and 2.Jaathasareera-prakrti) [1].

These factors determine the Psycho Somatic constitutional model (Prakrti $i$ ) which is considered as the primary factor in the health and wellness. The balanced constitution or the person with "Sama-prakrti" is considered the best and it is the perfect genetic makeup that a human being can have. Keeping this as the background, Ayurveda emphasises on various measures that have to be considered in the process of mother and child care in order to achieve a healthy offspring.

\section{Factors Influencing the Formation of Prakrti (Psycho Somatic Constitution) of an Individual}

\section{Ayurveda lists out various sets of factors influencing the Prakrti of an individual}

Maha-bhutha-vikaara-Prakrtimiha-Naraanaam-Bhowthikeem-

KechithAahu: Ayurveda states that life is a combination of 'PanchaMaha-Bhutha' or the five universal elements, viz. Aakasa (space, as the absence of resistance), Vayu (principles of movement, vibration), Agni (principles of change), Jala (principles of fluidity, cohesion) and Prithvi (principles of solidity or mass) in its gross form or as the five states of matter.Whenreferenced to life, these five elements arerepresented as the basis of all neurological functions (Vata), all metabolical functions (Pita) and all anabolic functions (kapha). Of these five, the predominant element of the sperm and ovum at the time of fertilization determines the Prakrti of a person. There is a detailed explanation of the subtle 24 principles transformed as purusha/ self based on this theory of evolution of a living organism [1].

Aathmaja bhavas" or soul or purusha origin: Factors transmitted from the "purusha" result in sensory perceptions, knowledge about self, qualities associated with mind, life force, etc. at a subtle level.

Prakrti is determined by the predominant features of the 'Tridoshas' (vatha, pitta, kapha) of Sukra (sperm) and Sonitha (ovum) [3].

The major influences on the Prakrti are explained in terms of: 'Kaala-garbhasaya' - the time and season of conception and the condition of the uterus; 'Aahaara-vihaara' -food habits and behaviour of the mother during pregnancy; 'Prathyathma' - the life styles of the parents, their thoughts and even occupation which in turn influence the Sukra and Sonitha; 'Jaathi-prasaktha' the unique features of the parents' race; 'Kula prasaktha' - the unique features of the community to which the parents belong; 'Desa-anupathini' - the unique features his/her country or region of birth and 'Kalanupathini - anupathini' age of the parents [1] (Figure 1).

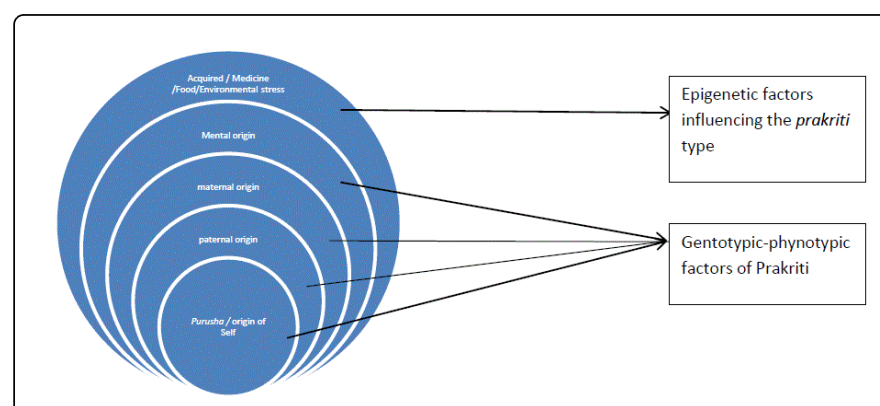

Figure 1: Epigenetic factors influencing Prakriti and Genotypicphynotypic factors of Prakriti.

Pithruja bhavas or paternal origin: Genetic factors transmitted from father for development of foetus includes factors related to male sexual organs, formation of head and hair on body parts, nail, teeth, bones, blood vessels, nerves and predominantly stable elements in the body. 
Mathruja bhavas or maternal origin: Genetic factors transmitted from mother for development of foetus includes factors related female sexual organs,blood, muscles, adipose, nervous tissues, skin, lymphatics, heart, liver, spleen, kidney, gastrointestinal system and predominantly soft tissues and elements in the body.

Satvajabhaavas or mental origin: Genetic factors transmitted predominantly from parents for development mental attributes of the foetus results in predominance of the qualities of satwa, raja and thamo guna which is predominant. This results in happiness, sorrow, greed, anger etc and memory and intelligence of the child.

Saatmyaja and Rasaja or acquired qualities: These qualities are acquired after birth by virtue or influence of environmental changes, food habits, and growth conditions that influence the behaviour [6].

\section{Genomics and its relationship with Prakrti}

The Human Genome Project (HGP) was an international scientific research project with the goal of determining the sequence of chemical base pairs which make up human DNA, and of identifying and mapping all of the genes of the human genome from both a physical and functional standpoint [6]. It was completed in the year 2003 and technological advancement in the field of DNA testing is so commendable that it has become a part of the medical field for diagnosis and treatment of various ailments.

However, outside the purview of Human Genomic Project, Scientists in India has conducted a correlative study to test the hypothesis of Prakrti and human genotyping, after evaluating subjects both for their HLA DRB1 types. The genomic DNA was extracted using standard protocol PCR-SSP, PCR-SSOP. A remarkable correlation has been established between HLA DRB1x62 allele, HLA DRBx13\&HLA DRBx10 and Prakrti types mentioned in Ayurveda [7].

The human classifications based on the body constitution as Vata, Pitta and Kapha prakriti in Ayurveda has formed the basis of disease management and for practicing traditional personalized medicine [8]. Several studies have attempted to associate single nucleotide polymorphisms (SNPs) to identify genetic basis of prakriti classification such as for HLA alleles [9].

Three major constitution types as Vata, Pitta and Kapha Prakriti have unique putative metabolic activities. Kapha is slow, Pitta is fast, while Vata is considered to have variable metabolism. We hypothesize that this may relate to drug metabolism and genetic polymorphism of drug metabolizing enzymes (DME). Inter-individual variability in drug response can be attributed to polymorphism in genes encoding different DMEs, drug transporters and enzymes involved in DNA biosynthesis and repair [10].

A Study on EGLN1 ( $\beta$-1,3-endoglucanase), a key oxygen sensor gene that negatively regulates the activity of hypoxia-inducible factor (HIF-1A) was conducted to explore molecular differences between three contrasting Prakriti types: Vata, Pitta, and Kapha. EGLN1 was one among 251 differentially expressed genes between the Prakriti types. EGLN1, a key oxygen sensor gene that negatively regulates the activity of hypoxia-inducible factor (HIF-1A) [11-13]. In the study, expression of EGLN1 gene and the association of rs479200 (C/T) and rs480902 (T/C) in highaltitude adaptation in relation to prakriti was reported. Hypoxia leads to the inactivation of EGLN1, thereby increasing HIF that induces the expression of genes, which mediates adaptive responses through glycolytic enzymes, hemeoxygenase (cellular level), vascular endothelial growth factor (local), and erythropoietin (systemic level). The study shows that expression and genetic analysis of healthy individuals phenotyped using the principles of Ayurveda could uncover genetic variations that are associated with adaptation to external environment and susceptibility to diseases [14-16].

Studies on DNA methylation and Prakriti: DNA methylation is a process by which methyl groups are added to DNA. Methylation modifies the function of the DNA, typically acting to suppress gene transcription. DNA methylation is essential for normal development and is associated with a number of key processes including genomic imprinting, X-chromosome inactivation, suppression of repetitive elements, and carcinogenesis [17].

Rotti $\mathrm{H}, \mathrm{R}$ et al, has established Differential DNA methylation signatures in three distinct prakriti phenotypes demonstrate the epigenetic basis of Indian traditional human classification which may have relevance to personalized medicine. Differentially methylated regions in $\mathrm{CpG}$ islands and shores were significantly enriched in promoters/UTRs and gene body regions. Phenotypes characterized by higher metabolism (Pitta prakriti) in individuals showed distinct promoter (34) and gene body methylation (204), followed by Vata prakriti which correlates to motion showed DNA methylation in 52 promoters and $139 \mathrm{CpG}$ islands and finally individuals with structural attributes (Kapha prakriti) with 23 and 19 promoters and CpG islands respectively. Bisulfite DNA sequencing of prakriti specific multiple CpG sites in promoters and 5'-UTR such as; LHX1 (Vata prakriti, SOX11 (Pitta prakriti) and CDH22 (Kapha prakriti) were validated. Kapha prakriti specific CDH22 5'-UTR CpG methylation was also found to be associated with higher body mass index (BMI) [12].

PCR: The polymerase chain reaction (PCR) is a technology in molecular biology used to amplify a single copy or a few copies of a piece of DNA across several orders of magnitude, generating thousands to millions of copies of a particular DNA sequence. Polymorphism is identified directly as part of the PCR process, although there are post amplification steps e.g. (SSP) Sequence specific primers (SSP) (group and alleles specific primers).

SSP: Sequence Specific Primers is a rapid method of typing that uses sets of primer pairs to amplify specific region of genomic DNA. The efficiency of the amplification reaction is controlled by the primers that amplify conserved sequences of a selected gene [15].

SSOP: This method involves selective amplification of target followed by hybridization to a panel of oligonucleotide probes. Specificity for a particular HLA locus was achieved by selecting PCR primers specific for a sequence in the conserved region of the second exon.

CpG islands: $\mathrm{CpG}$ islands typically occur at or near the transcription start site of genes, particularly housekeeping genes, in vertebrates. A C (cytosine) base followed immediately by a $G$ (guanine) base (a $\mathrm{CpG}$ ) is rare in vertebrate DNA because the cytosines in such an arrangement tend to be methylated.

\section{5'-UTR: untranslated region is the region of an mRNA.}

LHX1: LIM homeobox 1 is a protein that in humans is encoded by the LHX1 gene. This gene encodes a member of a large protein family which contains the LIM domain, a unique cysteine-rich zinc-binding domain.

Transcription factor SOX-11 is a protein that in humans is encoded by the SOX11 gene. 
$\mathrm{CDH} 22$ play an important role in morphogenesis and tissue formation in neural and non-neural cells during development and maintenance of the brain and neuroendocrine organs.

HLA: The term HLA refers to Human Leukocyte Antigens. The human leukocyte antigen system is the locus of genes that encode for proteins on the surface of cells that are responsible for regulation of the immune system in humans. HLA proteins are found in the membranes (outer coating) of nearly every cell in the body (all cells that have a nucleus). These antigens are in especially high concentration on the surface of white blood cells (leukocytes). Most individuals inherit a set of non-recombined HLA alleles from each parent. These genes are co-dominantly expressed. Thus if the HLA types of family member are determined, segregation of HLA types within the family can be used to construct the HLA types from each chromosome [15].

Naming of the HLA genes and alleles was published with updates by WHO as Tissue antigens ISSN-0001-2815.

\section{Tridosha:}

In Ayurveda Health and disease are described in terms of imbalance in the three functional principles (tri-doshas).viz. all the Neurological functions (Vata), All metabolic functions (Pitta) and all anabolic functions (Kapha) in their different combinations.

The author of this article on pharmacogenomics was one of the team members of the above study conducted by Rotti H, R et al.

\section{Pharmacogenomic in relation with Prakrtiand the EPIGENETIC factors mentioned in Ayurveda}

It also recommended that the phenotyping or the prakriti analysis alone is not sufficient to comprehend Pharmacogenomics approach of Indian traditional Medicine. The physician has to closely examine the following 10 factors. 1) Dusya factor: Body Tissue functions\&selection of medicine, 2) Desa factor: Habitat in which patient lives\&selection of medicine, Patients, 3) Bala factor: Strength\&immune factors in selection of medicine, 4) Kala factor: Chronobiology and selection of medicine, 5) Agni factor: Metabolic stage,digestive capacity \&selection of medicine, 6) Prakriti factor :Phenotype -Systemic functions\& selection of medicine, 7) Vaya factor: Age of the person\& selection of medicine, 8) Satva factor:Mental faculties\&selection of medicine. 9) Satmya factor: Homologation or wholesomeness\&selection of medicine, 10) Ahara factor: Food habit\&selection of medicine.

Food items suitable for one's Prakrti: Since food has profound influence on either increasing or decreasing a dosha, it is advisable to select food and drinks to suit one's Prakrti. They should be so chosen that they pacify the corresponding dosha vitiation. However, minor alterations can be made according to seasonal variations and availability of food items in each season. For instance, cold food items like ice creams are to be avoided in rainy season by Kapha Prakrti and Vata Prakrti individuals while it can be consumed during summer in limited amount, considering the changes happening in the body during summer. It is not advisable to change the food habits suddenly. There should only be a gradual shift to the prescribed diet. The right food habit is the first step towards good health.

Like food, life style and time of the day, the seasons also have profound effects on one's Prakrti. Individuals with Vata Prakrti are said to be more prone to ill health during rainy season, Pittha Prakrti individuals during autumn and Kapha Prakrti individuals during spring. Vitiation of doshas is said to be high during particular seasons.

Purificatory treatment procedures and Prakriti: As a result of improper metabolism, toxins (Aama) gets accumulated in the cells and cause acute and chronic ailments. These toxins (also understood as free radicals causing inflammations and metabolic disorders) needs to be eliminated from the body though methods of Pancakarma which include five purificatory measures (Emesis (vaman), Purgation (virechan), medicated enema (vastî), Nasal medication(nasya), and bloodletting (rakta moksa). It is advised to undergo seasonal purificatory process to increase strength and immunity of a person. For example, a Vata Prakriti person, should not undergo severe purificatory measures of emesis due to fear of disturbances in the neurological system. Similarly a Vata prakriti person should selected treatment protocols and medicines by selecting more medicated oil preparations for enema (vasti) in their purificatory (Panchakarma) treatment.

Based on the type of one's Prakrti, one can have a fair idea as to what kinds of disorders one is more prone to. In Ayurveda Vata type individuals are said to be prone to 80 specific disorders, Pitta prakrti individuals to 40 specific disorders and Kapha prakrti individuals to 20 sets of diseases entities. It is possible to extend the onset of such diseases or delay its pathogenesis if one is able to identify his/her Prakrti type.

\section{Conclusion}

Selection of appropriate medicine for a person Prakrti type is the most practical and time tested method followed in Ayurveda since ages. It is inexpensive and the methods are easy to remember and can be practiced easily by physicians and individuals for their health benefits. At the same time, the epigenetic factors are very essential to shortlist appropriate medicine for ones Prakrti type. The scientific studies carried out by various experts reconfirm the importance of Prakrti analysis and its role in innovative research programs in pharmacogenomics.

\section{References:}

1. (1992) The Charaksamhita of Agnivesha, edition 4th, Ed. Vaidya YadavajiTrikamji Acharya Munshiram, Manoharlal Publishers Pvt. Ltd., New Delhi.

2. Sushrut Samhita, Ed. Vaidya Yadavaji Trikamaji and Narayanram Acharya, Krishnadas Academy, Varanasi (reprint), Chaukhamba press, Varanasi.

3. (1995) Ashtangahridaya, Ed. Harishastri Paradakar Vaidya, Krishnadas Academy, Varanasi, Chaukhamba Press, Varanasi.

4. (2000) SharandharSamhita, Ed. Pt. Parashuramshastri Vidyasagar, Krishnadas Academy.

5. Murthy SKR, Bhavaprakash, edition 1st, Krishnadas Academy, Varanasi.

6. Nair VSN (2000) Prakruthi, FRLHT's Amruth.

7. (2008) Patwardhan, Promises of Integrative medicine, -case of AyurGenomics, Health for millions.

8. Jayasundar R (2010) Ayurveda: a distinctive approach to health and disease. Curr Sci 98: 908-914.

9. Bhushan P, Kalpana J, Arvind C (2005) Classification of human population based on HLA gene polymorphism and the concept of Prakriti in Ayurveda. J Altern Complement Med 11:349-353.

10. Evans WE (2003) Pharmacogenomics: marshalling the human genome to individualise drug therapy. Gut 52: ii10-ii18. 
Citation: SN Venugopalan Nair (2015) Knowledge of Pharmacogenomics in Indian Traditional Medicine -Ayurveda. J Pharmacogenomics Pharmacoproteomics 6: 150. doi:10.4172/2153-0645.1000150

Page 5 of 5

11. Rotti H, Raval R, Anchan S, Bellampalli R, Bhale S, et al. (2014) Determinants of Prakriti, the Human Constitution Types of Indian Traditional Medicine and its Correlation with Contemporary Science. J Ayurveda Integr Med 5: 167-175.

12. Rotti H, Mallya S, Kabekkodu SP, Chakrabarty S, Satyamoorthy K, et al (2015) DNA methylation analysis of phenotype specific stratified Indian population. Journal of Translational Medicine 13: 151.

13. Ghodke Y, Joshi K, Patwardhan B (2011) Traditional medicine to modern pharmacogenomics: Ayurveda Prakriti type and CYP2C19 gene polymorphism associated with the metabolic variability. Evid Based Complement Alternat Med 2011: 249528.
14. Aggarwal S, Negi S, Jha P, Singh PK, Stobdan T, et al. (2010) EGLN involvement in high-altitude adaptation revealed through genetic analysis of extreme constitution types defined in Ayurveda. Proc Natl Acad Sci USA 107: 18961-18966.

15. Salwa Hassan Teama (2013) Molecular HLA Typing, Molecular biology dept. Ain Shams University Cairo, Egypt.

16. All About The Human Genome Project (HGP).

17. Capuano F, Muelleder M, Kok RM, Blom HJ, Ralser M (2014) Analytical Chemistry. 